NBER - VIEST LIBRARY

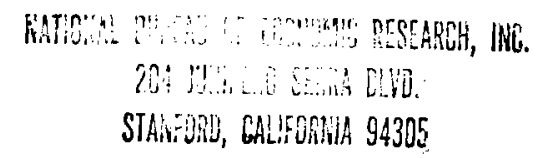

NBER WORKING PAPER SERIES

FURTHER EVIDENCE ON EXPECTATTONS AND THE DEMAND FOR MONEY DURING THE GERMAN HYPERINFLATION

Jacob A. Frenkel

Working Paper No. 289

\author{
NATIONAL BUREAU OF ECONOMIC RESEARCH \\ 1050 Massachusetts Avenue \\ Cambr1dge MA 02138 \\ October 1978
}

I am indebted to Craig S. Hakk1o for helpful comments and eff1clent research assistance. In revising the paper I have beneflted from useful corments by John B1lson, Kenneth W. Clements, Mohsin S. Khan, and Leonardo Le1derman. The research reported here is part of the NBER's research program in International Studies. Any opinions expressed are those of the author and not those of NBER. 


\section{Summary of \\ FURTHER EVIDENCE ON EXPECTATIONS AND THE DEMAND \\ FOR MONEY DURING THE GERMAN HYPERINFLATION}

by

Jacob A. Frenkel

Probably no event in monetary history has been more studied than the German hyperinflation of the early 1920's. Economists have been attracted to study this eplsode since it provides an environment that is close to a controlled experiment which 18 so rare in the study of social sciences.

Th1s paper provides further evidence on the role of expectations in effecting the demand for money during the German hyperinflation. One of the difficulties in studying empirically the role of expectations 18 the lack of an observable variable measuring expectations. Th1s paper examines three measures of expectations that are derived from observed data from the market for forelgn exchange. The first measure 18 based on the hypothesis that the forward exchange rate measures the expected future spot exchange rate and thereby provides an observable measure of the market's expectations concerning the depreciation of the currency. The other two measures distingulsh between the forward exchange rate and the expected exchange rate and are based on the supplementary hypothesis that rational behavior requires expectations to be unblased. Accordingly, the measures of expectations are constructed by using the forward exchange rate along with the information on the systematic relationship between forward and spot exchange rates. The varlous measures are then used in estimating the demand for money.

The emphasis on measures of expectations that are based on data from the forelgn exchange markets reflects the bellef that in an Inflationary economy with flextble exchange rates one of the relevant substitutes for holding domestic money is forelgn exchange.

Professor Jacob A. Frenkel Department of Economics Univers1ty of Ch1cago 1129 E 59th Street Ch1cago, Illinols 60637 (312) $753-4516$ 


\section{Introduction}

One of the difficulties in studying empirically the role of expectations is the lack of an observable variable measuring expectations. In two earlier papers dealing with the German hyperinflation of 1921-1923, I suggested the use of data from the foreign exchange market to measure expectations [Frenkel $(1976,1977)$ ]. Specifically, in estimating the demand for money, I used the forward exchange rate as a measure of the expected future value of the currency. An examination of the relationship between the forward and the spot exchange rates revealed that during that period the forward exchange rate seems to have underpredicted the future spot exchange rate. In Frenkel (1977) I indicated that this phenomenon need not be inconsistent with the rational expectations hypothesis which requires that individuals use efficiently all available information. Thus, one could expect that due to the lack of previous experience with hyperinfaltion, while individuals learn the new structure, mistakes would be made and expectations would therefore inftially underpredict the actual course of events [see Taylor (1975)]. Indeed, other evidence for the 1920's on the Franc/Pound, the Dollar/Pound and the Franc/Dollar exchange rates suggest that during a "normal" period, the forward exchange rate seems to have been an unblased forecast of the future spot exchange rate [see Frenkel (1978), Frenkel and Clements (1978), and Krugman (1977)].

In this paper I examine the implications of an alternative hypothesis concerning the measure of expectations. According to the alternative hypothesis, since expectations are unobservable, the expected exchange rate is assumed 
to be an unblased forecast of the future value of the spot exchange rate. The analysis draws on the conceptual distinction between the forward exchange rate and the expected future exchange rate. The relationship between these two rates 18 examined in Section $I$, which also contains estimates of the expected exchange rate. These estimates are then used to compute a time serfes of the expected rate of depreciation of the currency. Section II contains estimates of the demand for money, using the forward premfum on forefgn exchange and the expected rate of depreciation of the currency as alternative measures of expectations. Section III contains estimates based on an alternative estimation procedure with concluding remarks in Section IV.

I. The Forward Exchange Rate and the Expected Exchange Rate

In computing the expected exchange rate we first examine the relationship between the spot and the forward exchange rates by regressing the logarithm of the current spot exchange rate, $\ln S_{t}$, on the logarithm of the one-month forward exchange rate prevaling at the previous month, $\ell n F_{t-1}$.

$$
\ln S_{t}=a+b \ln F_{t-1}+u_{t}
$$

If the forward exchange rate is an unblased forecast of the future spot exchange rate, the constant term in equation (1) should not differ significantly from zero and the slope coefficient should not differ significantly from unity. ${ }^{1}$ Efficiency of the foreign exchange market requires that the residuals from the estimated regression be serfally uncorrelated. Equation

In principle, one could use in equation (1) the levels of the exchange rates rather than their logarithms. During the German hyperinflation, however, a regression using the levels of the exchange rates is completely dominated by the last few observations due to the rapid acceleration of the depreclation of the Mark. Data on the spot and forward rates are from Einzig (1937). For an analysis of the efficiency of the foreign exchange market and for extensive references to studies on the German hyperinflation see Frenke1 (1977). 
(1) was estimated over the period February 1921-August 1923, using monthly data on the Mark-Pound Sterling exchange rate. The length of the period was determined by the avallability of data on the forward exchange rate. The resulting ordinary-least-squares estimates are given in equation (2) with standard errors in parentheses below the coefficients.

$$
\begin{aligned}
& \ln S_{t}=\underset{(.253)}{-.454}+\underset{(.029)}{1.095} \ln F_{t-1}+u_{t} \\
& R^{2}=.98 ; \text { s.e. }=.456 ; \text { D.W. }=1.89
\end{aligned}
$$

As may be seen, the Durbin-Watson statistic indicates that the residuals are not serially correlated but that the slope coefficient is somewhat above unity (at the 95 percent confidence level). Furthermore, the joint hypothesis that the constant term is zero and that the slope coefficient Is unity is rejected at the 95 percent confidence level and thus, the forward rate seems to underpredict the future spot exchange rate. ${ }^{1}$

If the relationship between forward and spot exchange rates is stable (as in equation (2)), it may be reasonable to assume that individuals, In forming expectations, w1ll use the forward rate along with the knowledge of the relat lonship between forward and spot exchange rates that is described In equation (2). Thus, using the OLS estimates of equation (2), the expected future exchange rate for period $t$ (as of period $t-1$ ), may be computed as:

$$
E_{t-1} \ln S_{t} \mid(\text { OLS })=-.454+1.095 \ln F_{t-1}
$$

The series of expectations computed in equation (3) combines the use of the forward exchange rate wlth the assumption that the relationship between

${ }^{1}$ Strictly speaking, if the forward rate is an unblased forecast of the future spot rate, the constant term should equal $-.5 \sigma^{2}$ rather than zero. To see this, rewrite equation (1) as: $S_{t}=\exp \left\{a+u_{t}\right\} F_{t-I_{j}}^{b^{u}}$ Equating the mathematical expectation of both sides yields $E\left(S_{t}\right)=\exp \left\{a+\frac{1}{2} \sigma_{u}^{2}\right\} E\left(F_{t-1}^{b}\right)$; unblasedness requires that $E\left(S_{t}\right)=E\left(F_{t-1}\right)$ and thus implying that $a=-.5 \sigma_{u}^{2}$ and $b=1$. The hypothesis concerning the constant term cannot be refected by the estimates of equation (2) but the joint hypothesis that $a=-.5 \sigma_{u}^{2}$. and that $b=1$ is rejected. 
forward and spot exchange rates is part of the avallable information set that is used by individuals. These expectations are (by construction) unbiased forecasts of the future spot exchange rate. ${ }^{1}$

The computation of the series of expectations is subject to a conceptual difficulty since the estimates in equation (2) are based on data pertaining to the entire period (February 1921-August 1923). Thus, It contains information that was not avallable prior to the end of the period. The assumption underlying this procedure, however, is that the estimates in equation (2) are stable and do not depend on the choice of the period. To examine the validity of this assumption I divided the sample into two parts: "moderate" hyperinflation and "severe" hyperinflation where the latter period pertains to the last nine months of the inflationary process. A Chow test was performed on the estimates of equation (2) to test for equality of the coefficients between the two sub-periods' regressions. This test implies that (at the 95 percent confidence level) one cannot reject the hypothesis that the regression coefficlents do not differ between the two sub-periods. ${ }^{2}$ Thus, the data indicate that during that period, the

$1_{\text {For recent applications of the rational expectations hypothesis to }}$ the analysis of the German hyperinflation see Sargent and Wallace (1973) and Sargent (1977). The distinction between the forward exchange rate and the expected future spot exchange rate has been analyzed recently theoretically and empirically using the framework of portfollo theory. See for example, Bilson and Levich (1977), Fama and Farber (1977), Kouri (1976) and Stockman (1978). Generally speaking, this distinction does not seem to be of great quantitative importance; however, it might have been somewhat more important during the hyperinflation.

2 The F-statistic for the Chow test corresponding to the null hypothesis that the regression coefficients are the same for both sub-periods 182.17 while the critical values for $F(2,26)$ are 5.53 and 3.37 at the 99 and 95 percent confidence levels, respectively. In addition to the Chow test the dummy variables method was employed according to which the constant and the slope coefficients were allowed to differ between the two sub-perlods by including dummy variables for the "severe" hyperinflation period. None of the dummy variables was significantly different from zero at the 95 percent confidence level, indicating that one cannot reject the hypothesis that the structure has remained stable. To explore further the relationship between the two sub-periods I have used the parameter estimates from the first sub-period to predict the exchange 
relationship between spot and forward exchange rates has remained stable throughout the inflationary process and therefore, the conceptual difficulty mentioned above does not seem to be too serious.

It might be noted, however, that the residuals from the estimated regression in equation (2) show some degree of heteroskedasticity. Therefore, to obtain more efficient parameter estimates, equation (1) was reestimated by weighting the data from the two sub-periods by the Inverse of the estimated standard errors of the regressions corresponding to the two subperiods. The resulting weighted least squares (WLS) estimates are reported in equation (4): $:^{1}$

$$
\begin{aligned}
& \ln S_{t}=\underset{(.805)}{-.659}+\underset{(.035)}{1.066} \ln F_{t-1}+u_{t} \\
& R^{2}=.97 ; \text { D.W. }=1.84
\end{aligned}
$$

Using these WLS estimates, the expected future exchange rate for period $t$ (as of perfod $t-1$ ), may be computed as

$$
E_{t-1} \ln S_{t} \mid(W L S)=-.659+1.066 \ln F_{t-1} \text {. }
$$

Equations (3) and (5) yield two time series of expectations concerning the future exchange rate. Using these series one may compute two series of rate during the second sub-period. The correlation coefficient between the series of predictions and actual outcomes 1s.95. In addition. The11's (1961) inequality coefficient is extremely low (.027) of which the fraction due to the blas is only 8 percent.

When the residuals are heteroskedastic, the Chow test for equality of sets of coefficients in two regressions needs to be modified. Following the procedure suggested by Toyoda (1974) it was verified that, at the 95 percent confidence level, one cannot reject the hypothesis that the relationship between the spot and the forward exchange rates has remained stable throughout the two sub-periods. For a recent discussion of Toyoda's approximations see Schmidt and Sickles (1977). 
the expected one-month percentage rate of deprectation of the currency for the perfod between $t-1$ and $t$ (as of $t-1$ ):

$$
\pi_{1} \equiv E_{t-1} \ln S_{t} \mid \text { (OLS) }-\ln S_{t-1}
$$

and

$$
\pi_{2} \equiv E_{t-1} \ln S_{t} \mid(W L S)-\ln S_{t-1} ;
$$

In addition, using the series on the forward exchange rate, a third measure may be computed--the one-month forward premium on forelgn exchange: ${ }^{1}$

$$
\text { (1i1) } \quad \pi * \equiv \ln \mathrm{F}_{t-1}-\ln \mathrm{S}_{\mathrm{t}-1} \text {. }
$$

These three measures are based on information that is avallable as of period $t-1$. In the following section these varlables are used as proxies for expectations in estimating the demand for money.

\section{Estimates of the Demand for Money}

All standard theorfes of the demand for money predict that the demand depends on the expected cost of holding money. To the extent that money is held as a substitute for securities, the relevant cost is the rate of interest; to the extent that money is held as a substitute for ownership of goods, the relevant cost is the expected rate of inflation, while if domestic money is held as a substitute for forelgn money, the relevant cost is the expected change in the exchange rate. As a practical matter, however, incorporating the three margins in an empirical estimation of the demand may be quite difficult since the three measures of cost would be highly colinear in situations in which the purchasing power parity theory and the interest parity theory hold.

\footnotetext{
${ }^{1}$ Some aspects of the interrelationship between $\pi *$ and $\pi_{1}$ are examined
} in the Appendix. 
In Frenkel (1977) I estimated the demand for money using the forward premium on forelgn exchange $\left(\pi^{*}\right)$ as a measure of the expected cost. In a recent, Interesting paper, Abel, Dornbusch, Hulzinga and Marcus (1979) estimated the demand as a function of both margins of substitution--the expected change in the exchange rate (proxied by the forward premium on forelgn exchange) and the expected rate of inflation (proxied by the actual rate of inflation). They have shown that both measures of cost are significant and that the coefficlent of the expected change in the exchange rate Is about three times the slze of the coefficlent of the expected inflation. In this section I compare the estimates obtained by using $\pi^{*}$ with those obtained by using $\pi_{1}$ and $\pi_{2}$ as measures of the expected cost. Real balances are defined in terms of the cost of living index and the estimation is performed for two functional forms: the double-logarithmic and the semilogarithmic as in equations (6)-(7):

$$
\begin{aligned}
& \ln \left(\frac{M}{P}\right)_{t}=C+n \ln \pi_{t}^{*}+v_{t} \\
& \ln \left(\frac{M}{P}\right)_{t}=\varepsilon+\alpha \pi_{t}^{*}+v_{t}
\end{aligned}
$$

with analogous equations for $\pi_{1}$ and $\pi_{2} \cdot{ }^{1}$ The resulting estimates for the

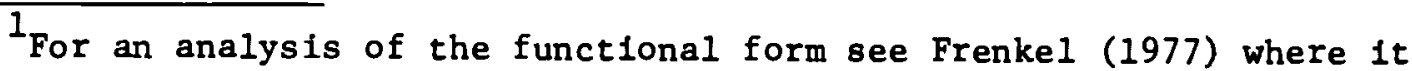
is also shown that the appropriate price deflator is the cost of 11ving index rather than the wholesale price index. Since during the earlier part of the hyperinflation the forvard premlum on forelgn exchange was negative (reaching -.8 percent per month in early 1921), I transformed the data on the forward premium and on the expected depreciation by adding one percent per month so as to permit an analys is of the double-logarithmic furictional form. This transformation was not sufficlent to make $\pi_{2}$ positive, and therefore, $\pi_{2}$ is only used in the semi-logarithmic functional form. Data on money and prices are from Graham (1930) and Tinbergen (1934). It may be noted that, for the semi-logarithmic regressions, the transformation only affects the constant term. In Table 1, the OLS results for $\pi$ * reproduce the corresponding estimates from Frenkel (1977). Those estimates are not 1dent1cal to the estimates in Abel et al (1979) due to a somewhat different method of interpolations, and due to a somewhat different cholce of timing. In equations $(6)-(7)$ the demand for money at period $t$ is assumed to depend on the forward premium as of perfod $t$, i.e., on $\pi_{t}^{*}=\ln \left(F_{t} / S_{t}\right)$; 
ordinary least squares and for the two stage least squares procedures are reported in Table 1. These results indicate that for the double-logarithmic functional form, the elasticity of the demand with respect to the expected cost of holding money is higher when expectations are measured by $\pi_{1}$ rather than $\pi *$. In both cases the two stage least squares estimation yields very similar estimates to those obtained by the OLS procedure, and in both cases, the estimated elasticities are close to the predictions of the various models of transactions and precautionary demand for money. For the semilogarithmic functional form, the OLS estimates of the semi-elasticity are somewhat higher than the corresponding 2SLS estimates. For both estimation procedures, however, the estimate of the semi-elasticlty is somewhat higher when expectations are measured by the forward premium $\pi$ * rather than by the two alternative measures.

When we allow for a distinction between short run and long run demand for money, the various measures of expectations yleld somewhat different estimates of the speed of adjustment. Consider for example a partial adjustment model, according to which the percentage rate of attaining the long run level of real balances is proportional to the logarithm of the ratio of the desired level to the actual quantity. The proportionality factor (denoted by $\gamma$ ) measures the speed of adjustment. The varfous parameters and the speed of adfustment may be estimated by Including a lagged value of real balances in the estimated regression of the demand for money. Table 2 reports the results of estimating the demand function with the lagged dependent varlable the corresponding specification in Abel et al (1979) is that (after December, 1921) the demand at period $t$ depends on $\pi_{t-1}^{*}=\ln \left(\mathrm{F}_{t-1} / \mathrm{S}_{t-1}\right)$. Since data on money balances are monthly averages, both specifications are reasonable approximations. However, the cholce of timing does affect the results. As Indicated by Abel et al (1979) when one uses $\pi_{t}^{*}$ rather than $\pi_{t-1}^{*}$, only the coefficlent of the forward premium is significant while that of the expected inflation is not. 


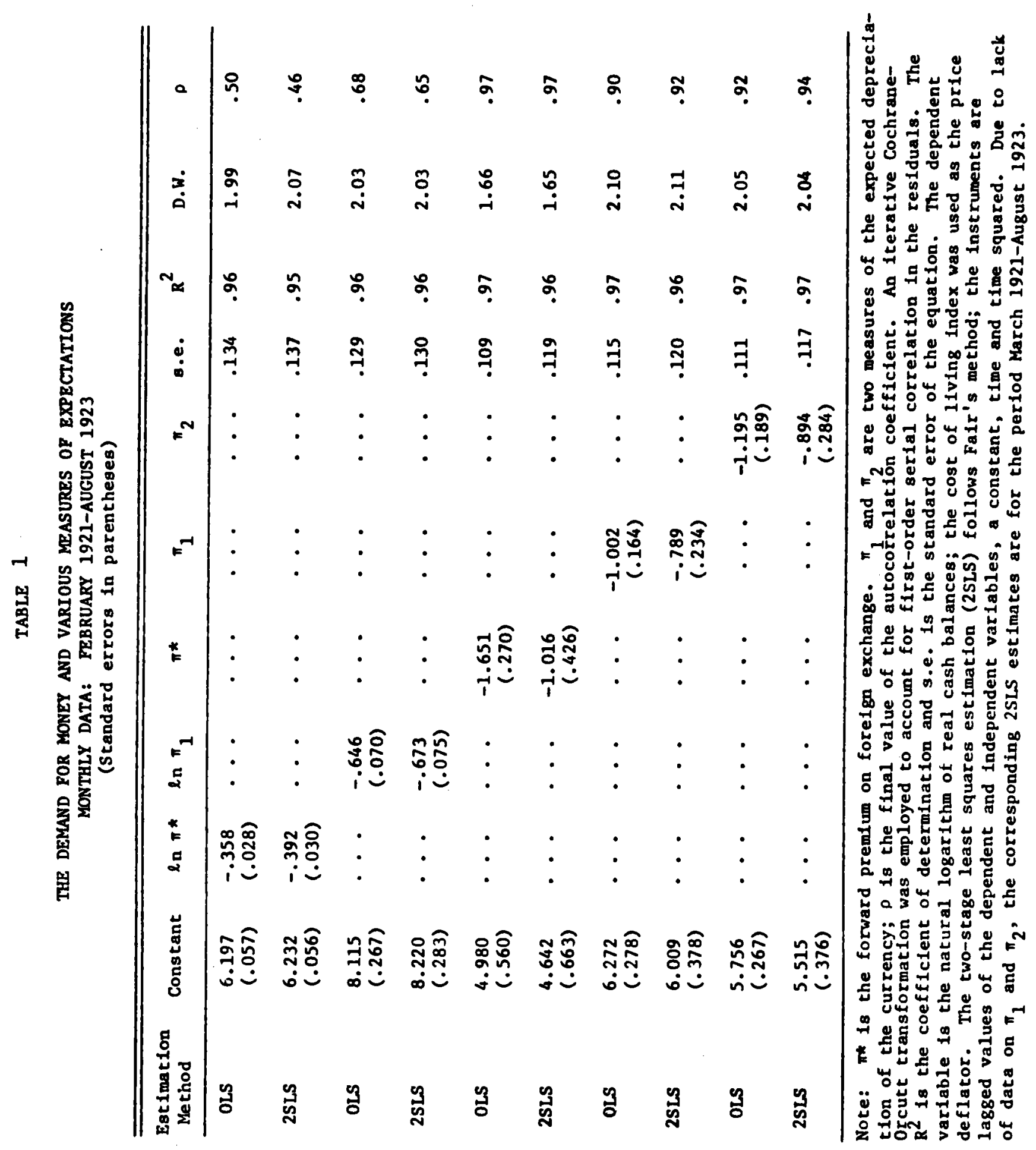




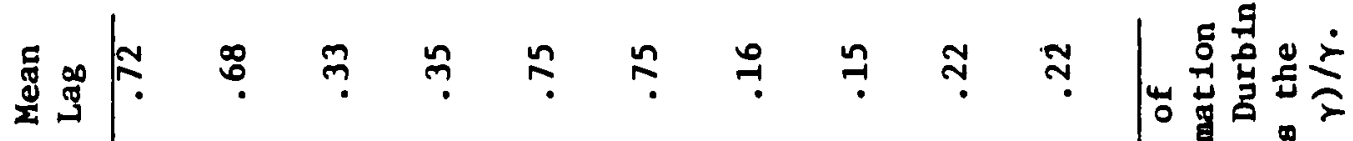

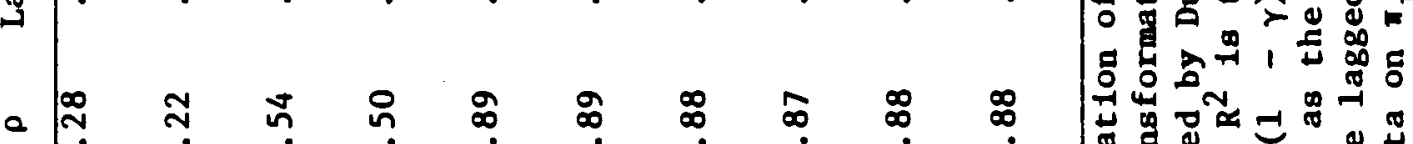

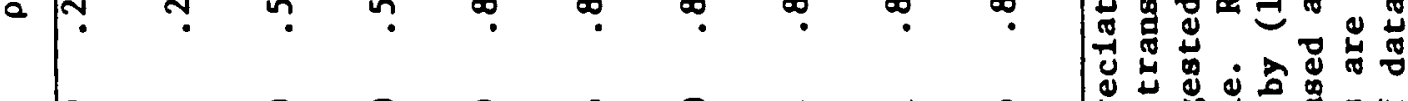

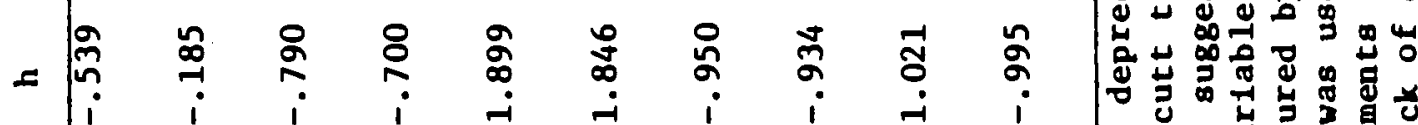

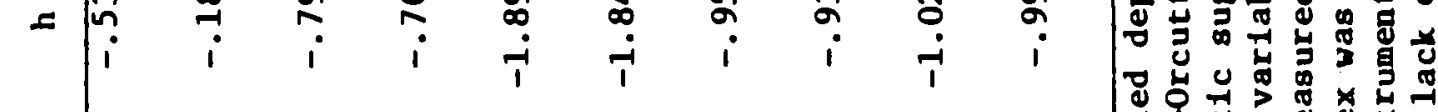
人 $)$ N

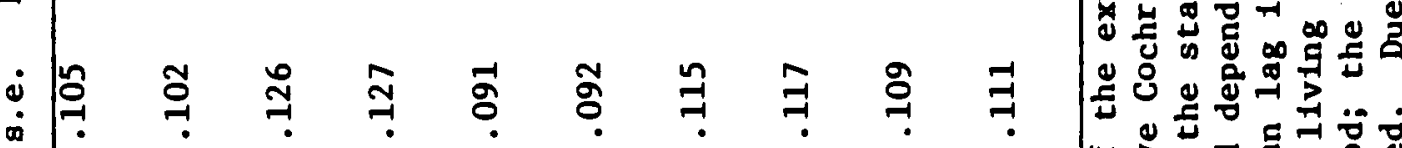

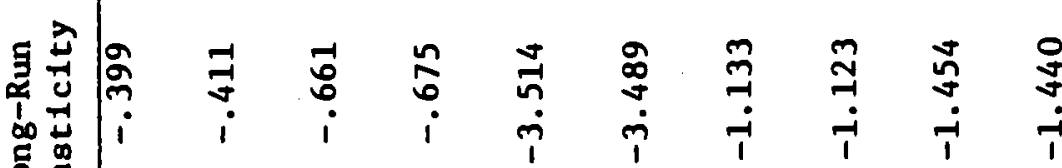

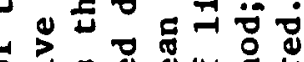

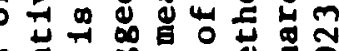

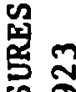

ยู่

ธू

$\rightarrow \widehat{0}$

$\rightarrow \rightarrow$

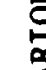

\&艺

光

웜

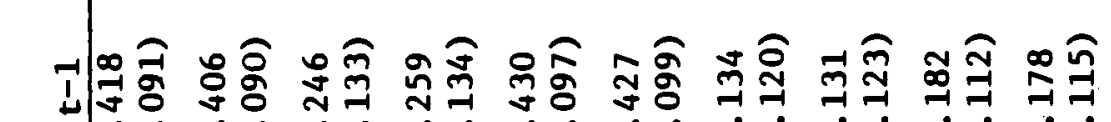

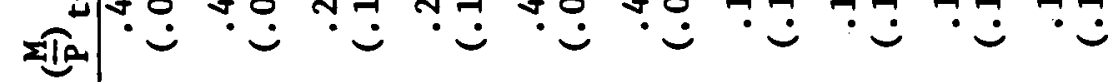

要

政

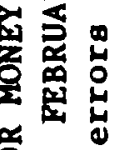

胥苾

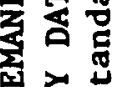

酉包

宁

운 इ

是

:

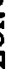

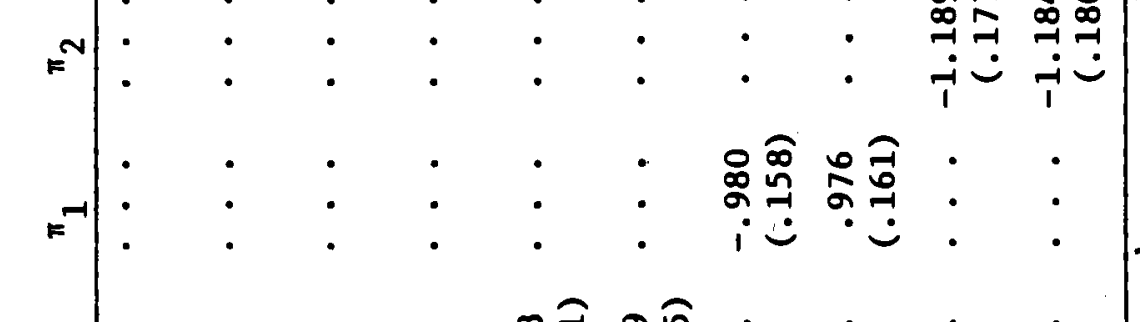

• $\cdot$ :

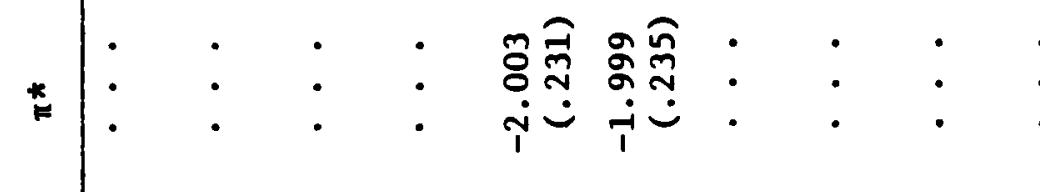

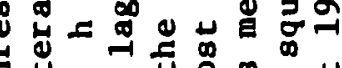

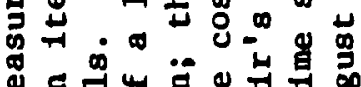

ช

(1)

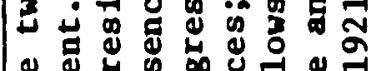

(4)

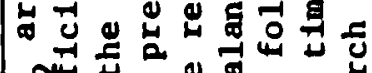

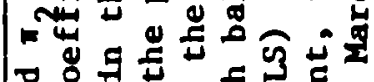

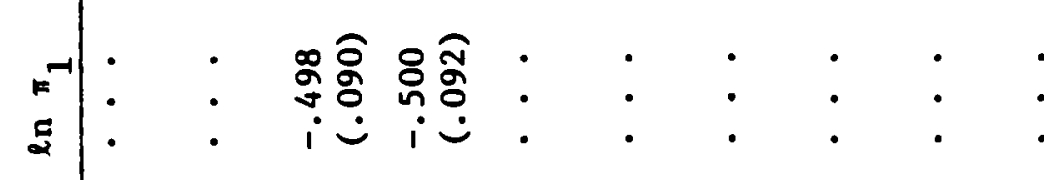

*

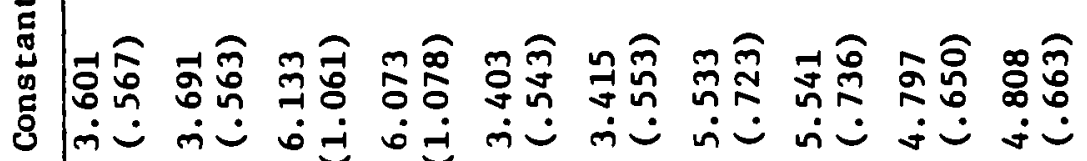

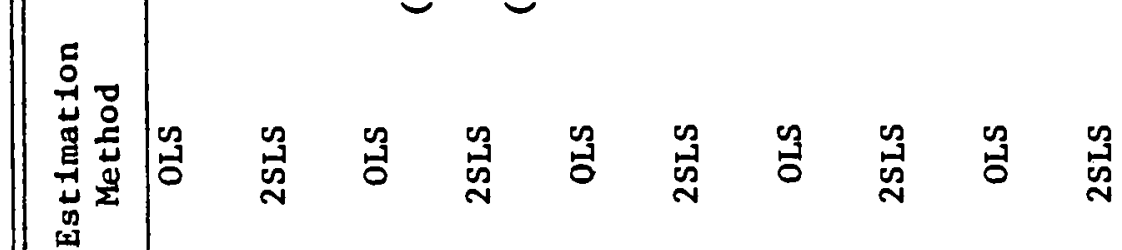

동 岁氖苞

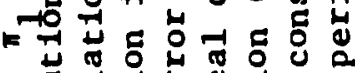

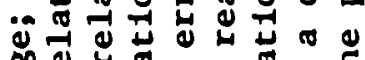

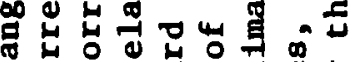

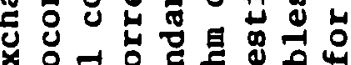

เे न

范出

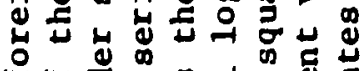

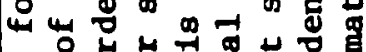

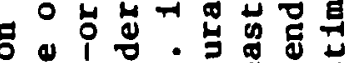

自寻密

F>出 出

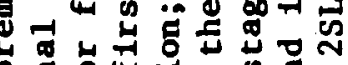

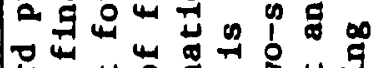

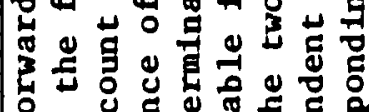

웜

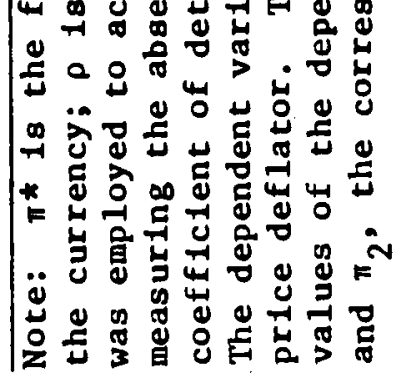


for the two functional forms using the three measures of expectations. Also reported in Table 2 are the estimates of the long run elasticities and the mean lag of adjustment. As can be seen, the relationships between the various elasticities are similar to those reported in Table 1 . The lagged dependent variable, however, is much less significant when expectations are measured by $\pi_{1}$ or $\pi_{2}$ rather than by the forward premium $\pi *$. Again, the estimates obtained by the OLS procedure are very simflar to those obtalned by the 2SLS procedure. The OLS estimates Imply that wher expectations are measured by $\pi *$, the 1mplled speeds of adjustment are .58 for the doublelogarithmic functional form and .57 for the semi-logarithmic form. When expectations are measured by $\pi_{1}$ the corresponding estimates are .75 and $; 87$ respectively where the latter does not differ significantly from unity. Likewise, when expectations are measured by $\pi_{2}$ the Implied speed of adjustment is .82 which does not differ significantly from unity. These estimates imply that when expectations are measured in terms of $\pi^{*}$, the time it takes to complete 90 percent of the stock adjustment 18 about 2.6 months for the double-logarithmic functional form and about 2.7 months for the sem1-logarithmic form. In contrast, when expectations are measured in terms of $\pi_{1}$, the corresponding estimates are about 1.6 and 1.2 months respectively. Simlarly, when they are measured by $\pi_{2}$ the corresponding estimate 18 about 1.4 months. It can be concluded that while the varfous measures of expectations yleld somewhat different estimates of the adjustment coefflcients, all indicate a relatively high speed of adjustment.

III. A Simultaneous Estimation of Expectations and the Demand for Money

The analysis in the previous sections followed a two-step procedure by which expectations were estimated in the first step and were then incorporated. 
In the second step into the estimation of the demand for money. The efficlency of the estimates can be increased by a jolnt estimation procedure. Furthermore,the hypotheses that expectations are unblased and that the relevant measure of the cost of holding money can be derlved from the relationship between forward and spot exchange rates, Impose some testable restrictions on the estimated parameters. In what follows I estimate the model simultaneously and test whether the data are . compatible with the restrictions that are 1mplied by the model. The analysis will concentrate on the semi-logarithmic functional form.

The demand for money is spectfled by equation (8) and the expected depreciation of the currency for the perlod between $t$ and $t+1$ (as of $t$ ) is spectfled by equation (9):

$$
\begin{aligned}
& \ln \left(\frac{M}{P}\right)_{t}=\varepsilon+\alpha \pi_{t}+v_{t} \\
& \pi_{t}=E_{t} \ln S_{t+1}-\ln s_{t} .
\end{aligned}
$$

From equation (1) the relationship between spot and forward rates is

$$
\ln S_{t+1}=a+b \ln F_{t}+u_{t}
$$

and thus:

$$
E_{t} \ln S_{t+1}=a+b \ln F_{t} \text {. }
$$

Substituting into (9) ylelds

$$
\pi_{t}=a+b \ell n F_{t}-\ln S_{t} \text {, }
$$

and substituting into ( 8 ) yields equation (12) as the demand for money.

$$
\ln \left(\frac{M}{P}\right)_{t}=\varepsilon+\alpha\left(a+b \ln F_{t}-\ln S_{t}\right)+v_{t} .
$$


The complete model is summarized by equations (10) and (12) which comprise the system of two equations incorporating the restrictions that are implied by the analytical framework; that is, the coefficients a and b appear in both equations In a specific way. Thus, estimating equations (10) and (12) simultaneously (by a nonlinear method) provide efficient estimates of the parameters and also permits testing whether the cross-equations restrictions are consistent with the data.

The resulting full information maximum likelihood estimates of the relevant parameters are: $a=-.901(.232), b=1.151(.027)$, and $a=-.933(.177)$ where asymptotic standard errors are in parentheses following the estimates. ${ }^{1}$ As may be seen, the estimated values of the various parameters are very simflar to those obtained by the two-step procedure. In order to test whether the data are compatible with the restrictions, the model was also estimated in an unrestricted fashion and the likelihood ratio test was performed. The difference between the logarithm of the maximum likelihood function of the restricted and the unrestricted model is -2.041 and thus, minus twice the difference is 4.082. According to the null hypothesis, minus twice the difference of the logarithmic likelihood between the null and the alternative hypothesis is distributed $\chi^{2}$ with one degree of freedom corresponding to the number of restrictions. The null hypothesis that the data are compatible with the restrictions cannot be rejected at the .975 percent confidence level for which the critical value of $\chi^{2}(1)$ is 5.024 ; it is however rejected at the .95 percent confidence level for which the corresponding critical value is $3.841 .^{2}$

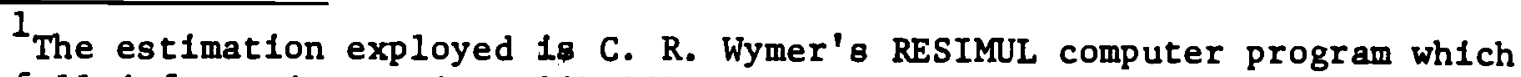
provides full information maximum likelihood parameter estimates of a system subject to nonlinear constraints. The last $t$ used in the estimation was August, 1923.

2 In addition to Imposing the cross-equation restrictions on the relationship between the parameters $a$ and b across equations (10) and (12), the model was also estimated with the added restriction that $a=0$ and $b=1$. Likewise, the model was also estimated with the restriction that the error term in equation (12) follows a first-order autoregressive process. The varlous parameter estimates were not affected materially but the joint restrictions, based on the likelihood ratio test, were rejected. 
IV. Concluding Remarks

Probably no event in monetary history has been more studied than the German hyperinflation. Economists have been attracted to study this episode since it provides an environment that is close to a controlled experiment which is so rare in the study of soclal sclences. The rise in the velocity of circulation when inflation accelerates was recorded by Lehfeldt (1922) and was rationalized in terms of expectations. ${ }^{1}$ The role of expectations In affecting the demand for money during the German hyperinflation has been analyzed in numerous studies following Cagan's (1956) classic contribution. The major difficulty, however, has been the lack of an observable varlable measuring expectations.

In this paper I have examined three measures of expectations that were derlved from observed data from the market for forelgn exchange. The first, which I used in Frenkel (1977), 1s based on the hypothesis that the forward exchange rate measures the expected future spot exchange rate. Accordingly, the relationship between forward and future spot exchange rates indicates whether or not expectations are blased. The other two measures distinguish between the forward exchange rate and the expected future rate, and are based on the supplementary hypothesis that rational behavior requires expectations to be unblased. Accordingly, the measures of expectations are constructed by using the forward exchange rate along with the information on the systematic relationship between forward and future spot exchange rates.

\footnotetext{
${ }^{1}$ It is interesting to note that in explaining the rapid rise in prices Lehfeldt used the rational expectations argument according to which current prices depend on current and on expected future money supply.

"Instead of the value of $P$ [the price level] depending only on the values of $Q$ [the money supply] at the moment, they are affected by anticipation of what $Q$ is likely to become; affected, of course, through the mechanism of speculative purchases and sales." (Lehfeldt, 1922, p. 559).
} 
These three measures were then used in estimating the demand for money during the German hyperinflation. It was shown that the resulting estimates, while differing in detalls from each other, do not lead to fundamentally different inferences concerning the properties of the demand for money. The emphasis on the various measures of expectations that are based on data from the foreign exchange market reflects the bellef that in an inflationary economy with flexible exchange rates one of the Important substitutes for holdings of domestic currency is forelgn exchange. To the extent that domestic money is held as a substitute for forelgn exchange, the specification of the demand for money should include the anticipated change in the exchange rate. 


\section{APPENDIX}

THE FORWARD PREMIUM, THE EXPECTED DEPRECIATION AND

THE RATE OF INFLATION: TEST OF "CAUSALITY"

In this Appendix, I examine the interdependence between the rate of Inflation and two of the meausres of expectations that were used in the paper. It is shown that the two measures $\pi^{*}$ and $\pi_{1}$ differ significantly in terms of their relationships with the rate of inflation. To examine the direction of "causality" (In the sense of Granger) between the measures of expectations and the rate of Inflation, I have employed S1ms' "causality" test and have calculated two-sided distributed 1 ag regressions. To test the hypothesis that there is no feedback from current inflation to future expectations, the current rate of Inflation 18 regressed on past and on current and future expectations. Sizable and significant coefficlents on future expectations lead to a rejection of the null hypothesis and permit the inference that inflation "causes" expectations in the Granger sense. To test the reverse hypothesis, that there is no feedback from current expectations to future rates of Inflation, a simflar procedure is followed with the reverse distributed lag.

The results of these tests are reported in Tables A-1 and A-2 which contain for each measure of expectations two regressions: one which includes future values of the independent varlable and one which does not. Also reported are the F-statistics relevant for testing the hypothesis that the coefficients of the future values of the independent varlables are zero. The results in Table A-1 suggest that when expectations are measured in terms of the forward 


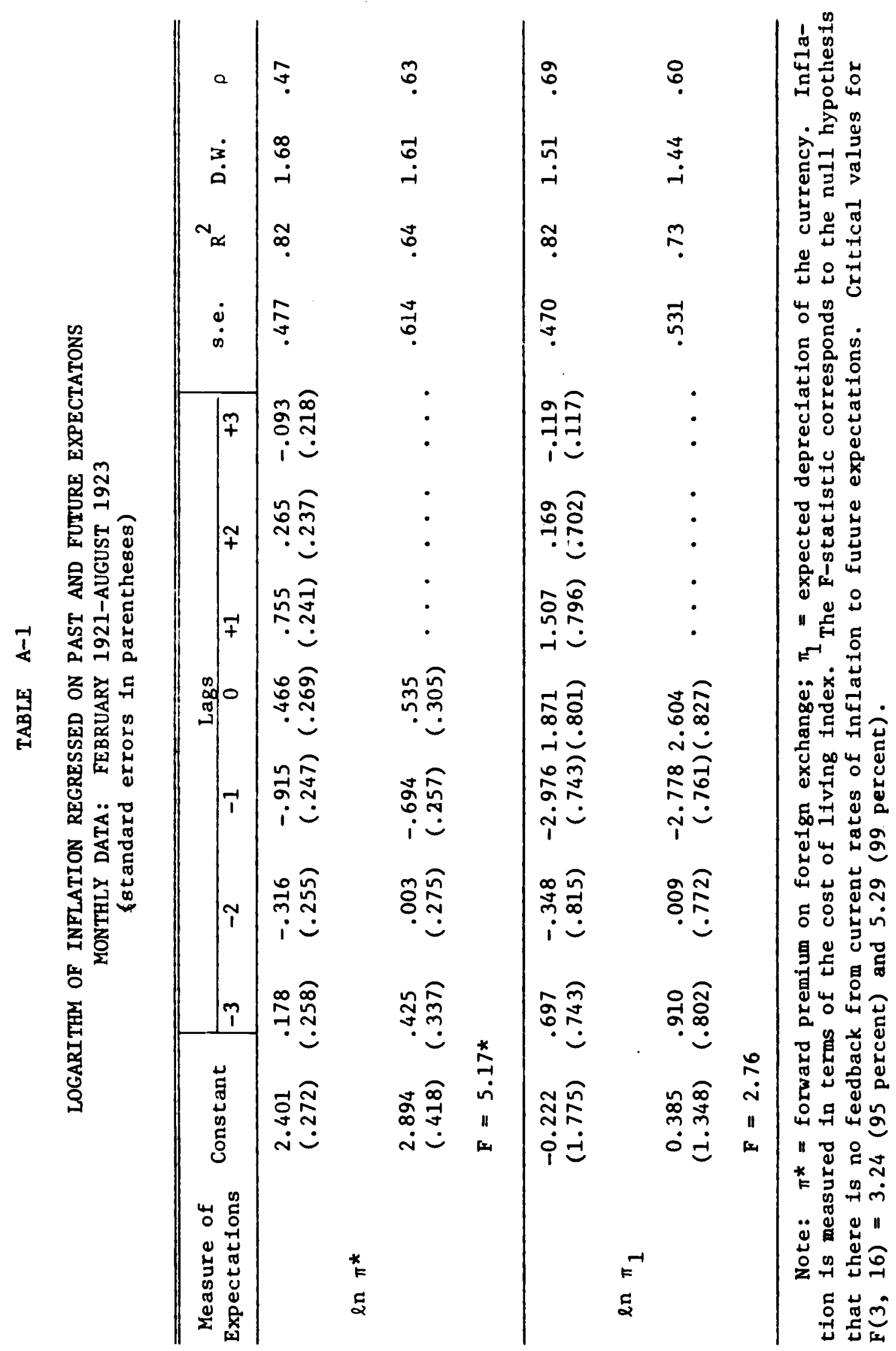


18

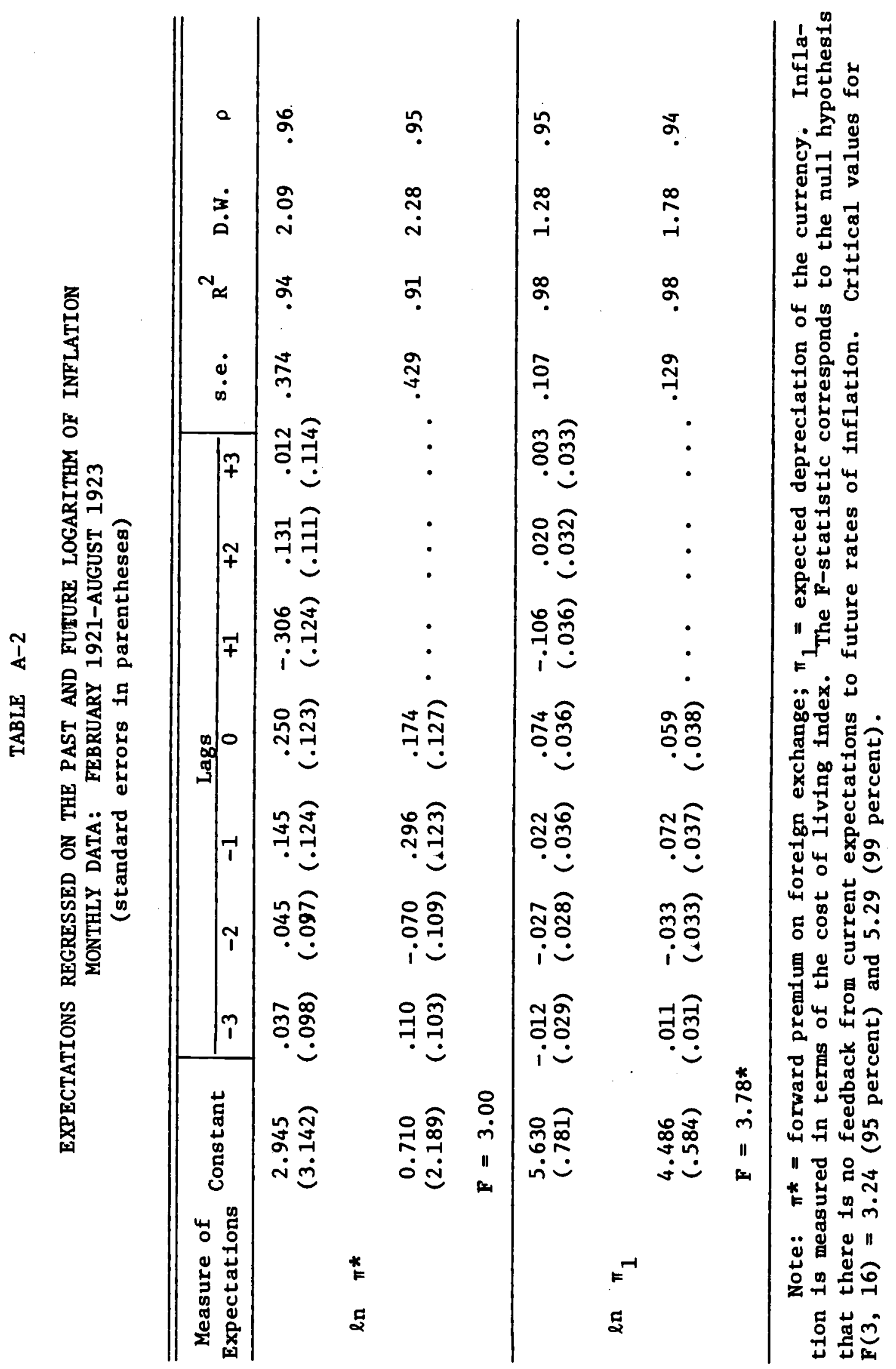


premium $\pi^{*}$, the null hypothesis that inflation does not "cause" expectations must be rejected since the F-statistic is 5.17 , well above the critical value of 3.24 (at the 95 percent confidence leve1). When expectations are measured in terms of $\pi_{1}$, the null hypothesis cannot be rejected since the F-statistic is 2.76, which falls below the critical value of 3.24 . On the other hand, the results in Table A-2 Indicate that when expectations are measured in terms of $\pi *$, one cannot refect the hypothesis (at the 95 percent confidence leve1) of no feedback from current expectations to future rates of inflation since the F-statistic is 3.00. When, however, expectations are measured in terms of $\pi_{1}$, the resulting F-statistic is 3.78 which leads to a rejection of the null hypothesis (at the 95 percent confidence level).

The foregoing analysis illustrates the significant difference between the two alternative measures of expectations by highlighting the interrelationships between these measures and the rate of inflation. As was Indicated in the text, however, when these measures are used as proxies for the expected cost of holding money, they do not yleld fundamentally different Inferences concerning the characteristics of the demand for money during the hyperinflation. 


\section{REFERENCES}

Abe1, Andrew; Dornbusch, Rudiger; Hulzinga, John; and Marcus, Alan. "Money Demand During Hyperinflation." Journal of Monetary Economics (1979) forthcoming.

Bilson, John F. O. and Levich, Richard M. "A Test of the Forecasting Efficlency of the Forward Exchange Rate." Unpublished manuscript, New York University, 1977.

Cagan, Ph1llip. "The Monetary Dynamics of Hyperinflation." In Milton Friedman (ed.) Studies in the Quantity Theory of Money. Chicago: University of Chicago Press, 1976.

Einzig, Paul. The Theory of Forward Exchange. London, 1937.

Fair, Ray. "The Estimation of Simultaneous Equation Models with Lagged Endogenous Varlables and First Order Serlally Correlated Errors." Econometrica 38, no. 3 (May 1970): 507-16.

Fama, Eugene F. and Farber, Andre. "Money, Bonds and Foreign Exchange." Unpublished manuscript, University of Chicago, 1977.

Frenke1, Jacob A. "A Monetary Approach to the Exchange Rate: Doctrinal Aspects and Empirical Evidence." Scandinavian Journal of Economics 78, no. 2 (May 1976): 200-224. Reprinted In Jacob A. Frenkel and Harry G. Johnson (eds.) The Economics of Exchange Rates: Selected Studies. Reading, Mass.: Addison-Wesley, 1978.

- "The Forward Exchange Rate, Expectations and the Demand for Money: The German Hyperinflation." American Economic Review 67, no. 4 (September 1977): 653-70.

- "Purchasing Power Parity: Doctrinal Perspective and Evidence from the 1920's." Journal of International Economics 8, no. 2 (May 1978): 169-91.

Frenke1, Jacob A. and Clements, Kenneth C. "Exchange Rates in the 1920's: A Monetary Approach." Unpublished manuscript, University of Chicago, 1978.

Graham, Frank. Exchange, Prices and Production in Hyper-inflation: Germany, 1920-23. Princeton: Princeton Univers1ty Press, 1930.

Kour1, Pentt1, J.K. "The Determinants of the Forward Premlum." Unpublished manuscript, Memorandum No. 204, Stanford University, 1976.

Krugman, Paul. "The Efficlency of the Forward Exchange Market: Evidence from the Twenties and the Seventies." Unpublished manuscript, Yale University, 1977. 
Lehfeldt, Robert A. "Statistics of Extremely Depreciated Currencies." Economic Journal 32 (December 1922): 557-560.

Sargent, Thomas J. "The Demand for Money During Hyperinflations under Rational Expectations: I" International Economic Review 18 (February 1977): 59-82.

Sargent, Thomas J. and Wallace, Ne1l. "Rational Expectations and the Dynamics of Hyperinflation." International Economic Review 14 (June 1973): 328-350.

Schmidt, Peter and Sickles, Robin. "Some Further Evidence on the Use of the Chow Test under Heteroskedasticity." Econometrica 45, no. 5 (July 1977): 1293-98.

Sims, Christopher A. "Money, Income and Causality." American Economic Review 62 , no. 4 (September 1972): 540-52.

Stockman, Alan. "Risk, Information and Forward Exchange Rates." In Jacob A. Frenkel and Harry G. Johnson (eds.) The Economics of Exchange Rates: Selected Studies. Reading, Mass.: Add1son-Wesley, 1978.

Taylor, John B. "Monetary Pollcy During a Transition to Rational Expectations." Journal of Polltical Economy 83, no. 5 (October 1975): 1009-21.

The11, Henr1. Economic Forecasts and Policy, 2nd ed. Amsterdam: NorthHolland, 1961.

Tinbergen, Jan (ed.) International Abstracts of Economic Statist1cs, 1919-1930. London, 1934.

Toyoda, Toshihisa. "Use of the Chose Test under Heteroskedasticity." Econometrica 42, no. 3 (May 1974): 601-8. 